\title{
Impact of Canavalia Cover Crop Management in Coffea arabica L. on Plant-Invertebrate Associations
}

\author{
Hermann A. Jürgen Pohlan ${ }^{*}, 1$ Marc J.J. Janssens ${ }^{1}$ and Bruno Giesemann Eversbusch ${ }^{2}$ \\ ${ }^{I}$ Rheinische Friedrich-Wilhelms-Universität Bonn, INRES, Tropischer Pflanzenbau. Auf dem Hügel 6, D-53121 Bonn, \\ Germany \\ ${ }^{2}$ Finca Argovia, $21^{\circ}$ Priv. Oriente \# 70, 30700 Tapachula, Chiapas, México
}

\begin{abstract}
Coffee ecosystems in the Soconusco, Chiapas, Mexico, with Coffea arabica are characterized by different cropping intensities, high diversity of soil and climate conditions. The main objective of this long-term study was the analysis of comprehensive relations between soil cover and weed-insect association. Biomass and weed cover community composition were analyzed together with weed-insect associations in coffee plantations that varied according to living soil cover management, weed control measures and coffee harvest traditions. Canavalia reduced significantly the presence of weeds. The treatment Canavalia + mulching under coffee plants produced with $3810 \mathrm{~kg} \mathrm{ha}^{-1}$ the significantly highest average coffee berry yield, peaking at $5457 \mathrm{~kg} \mathrm{ha}^{-1}$ in 2003. Significant correlations exist between Canavalia + weed management, year and coffee yield. The effects of different soil cover management regimes on the comparative biodiversity structures of weed - insects were evaluated between November 2002 and November 2003. Treatments with C. ensiformis supported smaller numbers of coffee berry borer (CBB) throughout the year. These data might be useful for new strategies in ecological coffee production.
\end{abstract}

Keywords: Canavalia, soil cover, weed-insect-associations, coffee yield, coffee berry borer.

\section{INTRODUCTION}

Chiapas is the most important coffee growing region of Mexico. The profitability tumbled down due to declining prices on the world coffee markets. This had a disturbing effect on the social and economic situation in the Soconusco, with 76000 ha of high diversity coffee ecosystems distributed between 450 and $1800 \mathrm{~m}$ above sea level (masl). It is by far the most productive and extended coffee growing area of Chiapas $[1,2]$. These eco-physiological conditions and weed management practices contributed to important changes in biodiversity of soil cover, weed competitiveness and in concomitant weed-insect associations [3-6]. Different studies in tropical crops showed the utility of leguminous species as soil cover crops, soil erosion controller, green manure and positive ecosystem enhancer [7-9]. Reviews of the impacts of weeds on arthropods in temperate agro-ecosystems focused either on using weeds as a component of plant diversity to manage beneficial arthropods or took a narrow view of the ecology driving interactions, or were limited to implications for systems of arthropod management [10].

The coffee berry borer (CBB / Hypothenemus hampei Ferrari; Coleoptera: Curculionidae) resurged and is actually the most important pest of coffee, not only for C. canephora but also for the low elevation C. arabica. Its biological control has been studied $[11,12]$, but the interactions between type of soil cover, this Scolytidae and other insects are relatively unknown $[13,14]$.

\footnotetext{
*Address correspondence to this author at the Rheinische FriedrichWilhelms-Universität Bonn, INRES, Tropischer Pflanzenbau. Auf dem Hügel 6, D-53121 Bonn, Germany; E-mail: JPohlan@t-online.de
}

For four consecutive years, the impacts of different soil cover managements were analyzed, as well as their biomass production and nutritional uptake on different growth and yield parameters of $C$. arabica. Additionally we undertook population dynamic studies of CBB and other insects between November 2002 and November 2003. The objectives of this long term-experiment were: (i) determining the potential of Canavalia ensiformis L. as a temporary cover crop in coffee, (ii) analysing the interaction between $C$. ensiformis and the natural weed population, (iii) studying the interactions of weed - insect associations, and (iv) determining the effects of soil cover management on growth and yield of Arabica coffee.

\section{MATERIAL AND METHODS}

\section{Site Description}

Field experiments were conducted from 2001 to 2004 on the Finca Argovia, $\left(15^{\circ} 07^{\prime} 962^{\prime}\right.$ ' N, 92 ${ }^{\circ} 18^{\prime} 177^{\prime}$ ' W, altitude 622 masl and average inclination of $48 \%$ ) to determine the effects of different soil cover periods with Canavalia ensiformis L. and of natural weed community on the growth and yield parameters of coffee (C. arabica L.), cv. Caturra [2]. The soil is classified as an Andosol with good physical and chemical properties for coffee cultivation [1]. Typical for this soil are high contents of manganese, iron and copper. The $\mathrm{pH}$ and phosphorus are low and the soil is high in organic matter. In the region of the Soconusco, rains are influenced by the topography: the cold fronts descend from the Pacific Ocean and strike 'la Sierra Madre', which stands like a north-south mountain barrier in Chiapas. A clear division between the rainy season and the dry season does exist in the coffee areas of the Soconusco. The climate is determined as $\mathrm{Am}(\mathrm{w})$. The raining season is bimodal. Nearly all zones in 
the region are characterized by high annual precipitation. The average annual precipitations in Argovia vary between $3334 \mathrm{~mm} /$ year and $4800 \mathrm{~mm} /$ year with a bimodal distribution.

\section{Plot Design and Treatments}

The experimental design consisted of 3 strips of each 120 x $20 \mathrm{~m}$ across 6 treatments or main plots. Each main plot is divided in 3 subplots or repetitions, each including 144 coffee trees and measuring $20 \times 20 \mathrm{~m}$. Treatment main plots were not randomly allotted but laid out in a systematic fashion. The control treatment (a6) without Canavalia was laid out at the beginning of a Canavalia gradient consisting of delaying more and more the periodic chopping i.e. monthly trimming in a1, Canavalia chopping in February (a2 \& a3), and Canavalia cut at the very end of the dry season (a4 \& a5). Departure from random plot/subplot assignment was intended to keep homogeneous entities (Control vs Canavalia) and reducing neighbourhood biases due to repellent/attraction effects of cover crop. The complementary effect of spreading the trimmed off Canavalia under the coffee tree canopy as mulch can possibly be identified with treatments a3 and a5. If non significant the latter treatments would provide further repetitions for a 2 and a 4 respectively.

In each treatment with subplot size of $20 \times 20$ m twelve random coffee trees samples were marked and recorded. Statistical analysis does not present significant differences between the three strips although they were laid along the most visible altitudinal gradient. Soil cover and trap analyses were replicated 4 times per plot. During 4 years, growth and yield parameters of coffee were recorded and the abundance and dominance of natural weed community and of soil cover represented by $C$. ensiformis determined at two-monthly interval.

The comparative biodiversity structure of weed - insects associations was evaluated between November 2002 and November 2003. In this period, the coffee berry borer (CBB / H. hampei) and other insects were captured 14 times with ECO-IAPAR - traps during 48 hours each [12] at 2 elevations $(50 \mathrm{~cm}$ and $150 \mathrm{~cm})$. The results of this capture are presented in average values. The coffee berries were harvested at full maturity. The correspondent harvest dates were: year $2001 \quad(10.10 . / 31.10 . / 25.11)$, year 2002 (29.10./12.11./6.12.), year 2003 (25.10./25.11.) and year 2004 (17.11.). The experimental plots were monitored monthly. A survey of all soil cover vegetation and coffee growth parameters was conducted in two-monthly intervals.

\section{Statistical Analysis}

All data were tested for normal distribution and logtransformed where applicable to meet assumptions of normality. Taking years as one factor and Canavalia management as a second factor, analyses of variance (ANOVA) were performed using two-way analysis with the standard error of the difference between treatment means (SED) to separate treatment means $(P=0.05)$. Correlations between weed and coffee parameters were calculated. Different regressions models were tested for best fit between coffee yield and cover crop management. The coffee berry borer dynamics were plotted cumulatively. All statistical analyses were performed with the help of the "Statgraphics Version 5.1" package.

\section{RESULTS}

\section{Biomass and Dynamics of Soil Cover}

The results of the present study demonstrate clearly the importance of selecting carefully on-site adapted and noncompetitive species like Canavalia. Canavalia production was prolific in the first year for all treatments. With increasing plant height and branch number of coffee plants, Canavalia growth in the years 2002 to 2004 was gradually suppressed over time. In the first year the contribution of Canavalia to the biomass oscillates between 93 and $99 \%$. With the ripeness of Canavalia at the end of March, treatments a1, a4 + a5 allow more light penetration to the soil surface which in turn allows the steady emergence of weeds. The appearance of monocotyledonous and broad-leaved weeds increase from year to year due to the reduced distribution of Canavalia in the soil cover (2004: 45 to $51 \%$ ) and the significant smaller biomass production of Canavalia under stronger shadow conditions shed by the older coffee plants (Fig. 1). The most important monocotyledonous species during the four year observations were Commelina spp., Oplismenus burmannii (Retz.) P. Beauv., Cyperus spp. and Tripogandra spp. Broad-leaved weeds do not reach the importance of monocotyledonous weeds during the rainy season as the former ones consist of non aggressive species like Blechum pyramidatum (Lam.) Urb., Drymaria cordata (L.) Willd. ex Roem. \& Schult., Impatiens spp. and Hyptis capitata Jacq. In the dry season of 2003 and 2004 the species Achyranthes aspera Linn. became very dominant and was very uncomfortable for the workers.

The biomass production of weeds during the rainy seasons was strongly influenced by the shade conditions in the coffee plantation. One serious problem in the rainy season of the first two years was the presence of different very dominant climbing species: Ipomoea spp., Epipremnum aureum Linden ex André, Momordica charantia L., Cucumis spp. and Rytidostylis ciliate (Jacq.) Kuntze. To ascertain accurately the effects of Canavalia succession on the weed biomass after cutting Canavalia, were analyzed in the rainy season the respectively weed biomass. Only the treatment weed slashing by hand every 2 month (a 6: conventional) showed significant effects caused by the high number of weed cleaning labours in the years 2001 to 2003. Between the different soils cover treatments with Canavalia no statistical differences are found. The weed biomass in the rainy season of the year 2001 was influenced stronger by the succession of Canavalia than in the year 2002. In the years 2003 and 2004 the coffee plant canopies exerted higher selfshadowing and hence, decreased the weed cover and biomass from an average in 2003 between 1220 and 1973 gm- $^{2}$ and from 418 to $1205 \mathrm{gm}^{2}$. The biomass in the conventional weeded treatment (a6) was higher in 2003 and 2004 than in 2001 and 2002, because of reduced cleaning labour (only one cut between April and July).

\section{Effects of Soil Cover on Coffee Yield}

Coffee yield peaked in 2003 for the two February treatments a2 and a3, and particularly in treatment a3 (Canavalia 


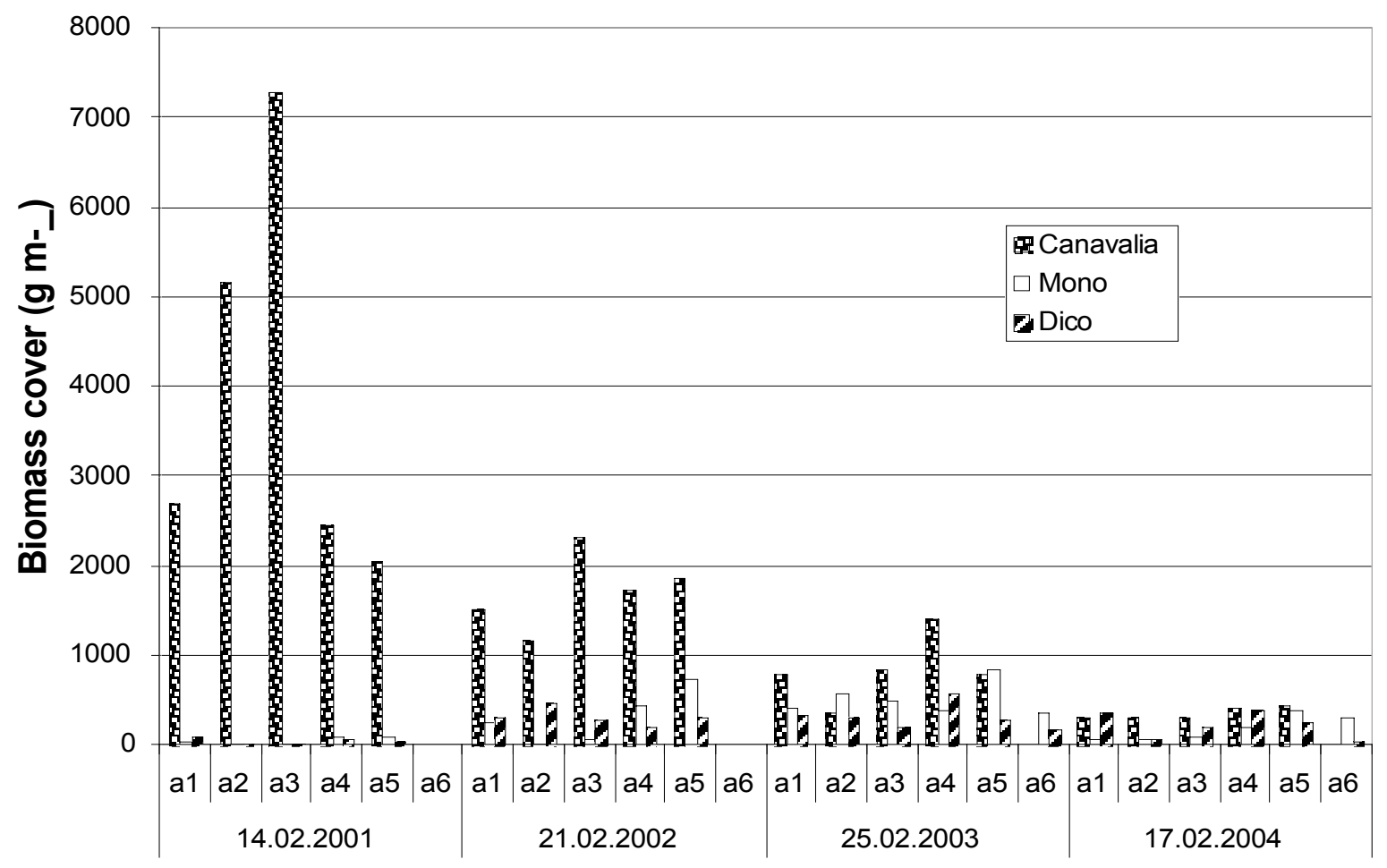

Fig. (1). Biomass production of soil cover, respectively for Canavalia, broad-leaved weeds and monocotyledons in the years 2001 to 2004 (spring season, LSD $0.05=653$ ).

cut in February and mulching under coffee plants) with 7800 $\mathrm{kgha}^{-1}$ coffee berries. The two April treatments a4 and a5 were more persistent up into 2004, yet at a lower yield level (Fig. 2). The comparison between the treatments with Canavalia cover and conventional weed control give every year advantages for the Canavalia treatments. The relation of the mean average yields are in the year 2001: 1041.2 to 885.3 $\mathrm{kgha}^{-1}$; 2002: 1542.8 to $1166.7 \mathrm{kgha}^{-1}$; 2003: 5875.8 to $3365.3 \mathrm{kgha}^{-1}$; and 2004: 2101.6 to $2178.7 \mathrm{kgha}^{-1}$. The yearly cumulative coffee berry yield show the impact of the different cover management with Canavalia and without Canavalia. In all years present the treatment Canavalia cut in February and mulching under coffee plants the highest yields, followed by Canavalia cut in February and mulching between coffee rows.

The yield of coffee was significant influenced by the type and the management strategy of Canavalia cover. With 3810 $\mathrm{kg}$ of coffee berries per hectare the treatment with Canavalia cut in February and mulching under coffee plants (a3) produce significantly the highest yield (Table 1). The lowest yield was measured in the treatment without Canavalia (1899 $\mathrm{kg} \mathrm{ha}^{-1}$ ).

Yearly alternance of coffee reproduction is well known. This natural phenomenon was also found in this investigation. The two first years after transplanting, yield was normally low and in 2003 the highest yield $\left(5457 \mathrm{~kg} \mathrm{ha}^{-1}\right)$ was reached.

This 4-year experiment give clear information about the correlations between coffee yield and the different soil cover treatments. Coffee yield is correlated with aging $(\mathrm{r}=0.44)$. Canavalia fresh matter to the contrary is vigorous in the early stage of coffee planting but diminishes rapidly with aging and is slightly competing with coffee $(r=-0.26)$.

Simple linear regression between coffee yield and Canavalia was non significant. There exists a high significant correlation between Canavalia biomass and the companion weed biomass. However, Canavalia mass diminishes over years. Effects of year are clearly dominating as illustrated by the second order polynomial regression of coffee yield upon year, whereby determination of $49 \%$ was reached.

\section{Soil Cover - Weed - Insect Associations}

The observations over the weed - insect associations were realize between November 2002 and November 2003 including two typical traditional coffee systems, which are boarding the experimental area in addition to the standard treatments of the long term experiment,. The treatments with C. ensiformis presented smaller appearances of the coffee berry borer (CBB / Hypothenemus hampei) during the whole year. Between the end of March and start of June the number of captured $\mathrm{CBB}$ increase more than $500 \%$ in comparison to the other months (Fig. 3). The $150 \mathrm{~cm}$ high traps captured more $\mathrm{CBB}$ than those at $50 \mathrm{~cm}$ height. The capture of $\mathrm{CBB}$ was strongly influenced by the soil cover. Cumulative average values of the treatments with Canavalia (a1 to a5) were smaller in the two different trap heights than in the treatments without Canavalia. The number of captured CBB in $50 \mathrm{~cm}$ height and by Canavalia soil cover was reduced on 50 $\%$ against treatments without Canavalia in both trap heights. $\mathrm{CBB}$ numbers in the treatments without Canavalia (control) do not present differences at both trap heights. 


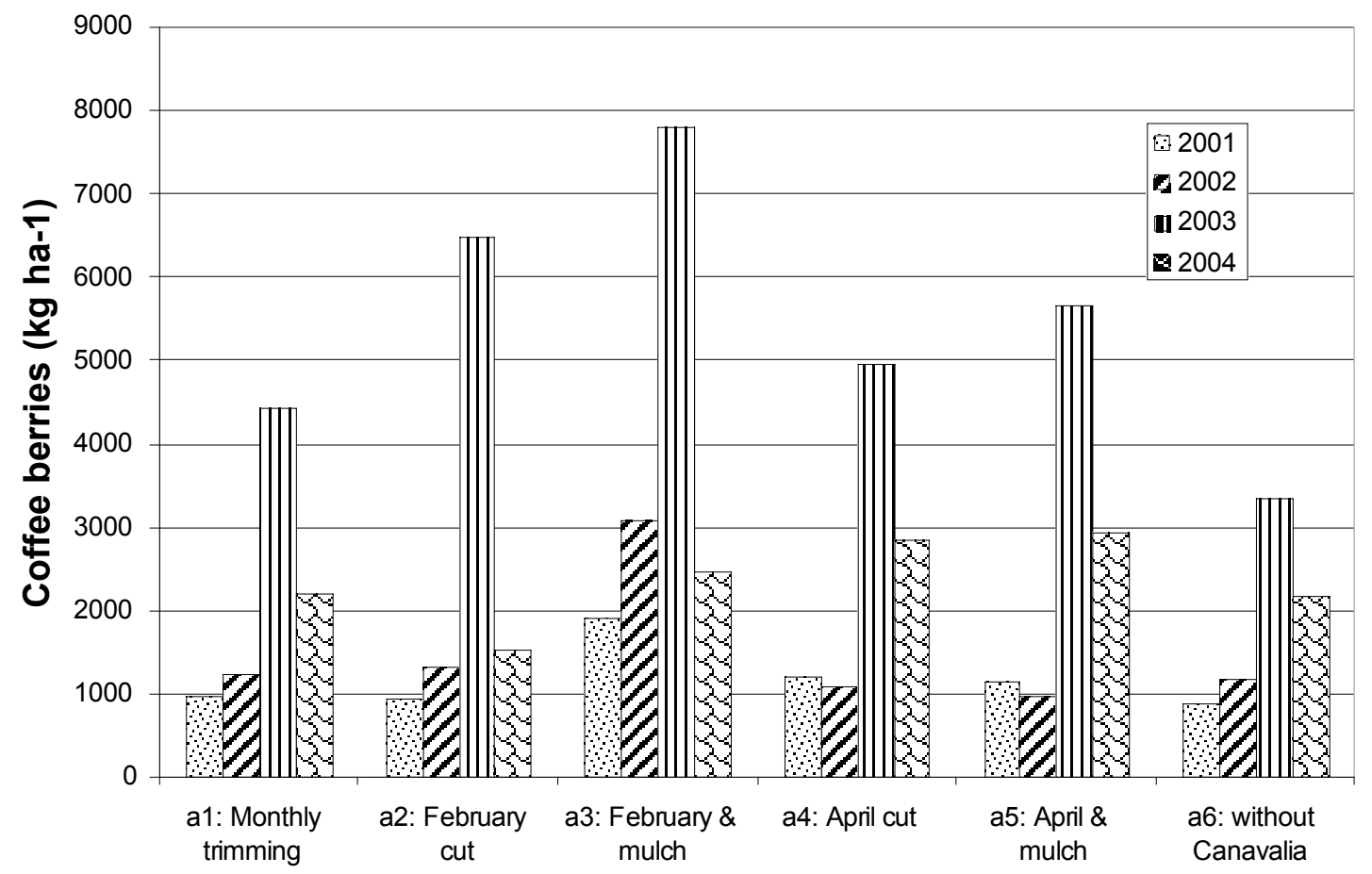

Fig. (2). Effects of different soil cover management and year on coffee yield (The pooled LSD value at $\mathrm{p}=0.05$ for year by treatment interactions is $925 \mathrm{~kg} \mathrm{ha}^{-1}$ of coffee berries).

Table 1. Comparison of Treatment Means for Coffee Yield, Fresh Matter of Herbaceous Cover and of Canavalia

\begin{tabular}{|c|c|c|c|c|c|}
\hline \multicolumn{2}{|c|}{ Coffee Berry Yield } & \multicolumn{2}{|c|}{ Total Biomass Cover } & \multicolumn{2}{c|}{ Canavalia } \\
\hline Treatment & kg ha $^{-1}$ & Treatment & $\mathbf{g ~ m}^{\mathbf{2}}$ & Treatment & $\mathbf{g ~ m}^{\mathbf{2}}$ \\
\hline \hline 6 & $1899 \mathrm{a}$ & 6 & $457 \mathrm{a}$ & 5 & $1289 \mathrm{a}$ \\
1 & $2219 \mathrm{ab}$ & 1 & $2782 \mathrm{~b}$ & 1 & $1339 \mathrm{a}$ \\
4 & $2531 \mathrm{~b}$ & 4 & $3502 \mathrm{bc}$ & 4 & $1502 \mathrm{ab}$ \\
2 & $2579 \mathrm{~b}$ & 2 & $3719 \mathrm{~cd}$ & 2 & $1757 \mathrm{~b}$ \\
5 & $2688 \mathrm{~b}$ & 5 & $3836 \mathrm{~cd}$ & 3 & $2692 \mathrm{c}$ \\
3 & $3810 \mathrm{c}$ & 3 & $4520 \mathrm{~d}$ & & \\
\hline
\end{tabular}

*Values in the same column followed by a different letter are significantly different at the 0.01 probability level.

In the system with conventional weed management and Inga shade trees (a6: control without Canavalia) we found the highest CBB presence. Indeed, capture frequency at 50 $\mathrm{cm}$ of height was at least thrice as much as in the Canavalia covered plots. Cutting Canavalia in February and mulching it under the coffee trees resulted in lowest coffee borer incidence.

Additionally, the abundance, diversity and dynamics of other insect populations into the coffee plantation were determined (Table 2). Most abundant in both heights were the Hymenoptera, followed by Diptera, Homoptera and Coleoptera. Number of captured insects was greater in traps located at $150 \mathrm{~cm}$. The Hemiptera, Orthoptera and Collembola present much more individuals at $50 \mathrm{~cm}$ height.

\section{CONCLUSION}

Effects of Canavalia on the Biomass and Dynamics of Soil Cover and Coffee Yield

In different tropical perennial crops it is common practice to manage natural weed or to sow cover crops for soil conservation and green manure. The floristic composition of this living soil cover is very important for tuning either its aggressiveness against or its benefit for the perennial crop.

Canavalia presents high competitive ability against weeds. This competition affects the weed growth not only in during their growing cycle in the dry season but also in the rainy season and hence, reduces weed biomass production. This can be exploited to enhance the effect of partial weed suppression and therefore, to reduce weed control activities. However, more plant height of coffee and increased branch number reduce the light penetration into the coffee rows and influence the growth dominance of Canavalia. These results are of practical interest, for it is only recommendable to sow Canavalia as cover plant in young coffee plantation or after cutting coffee rows.

Very interestingly, Canavalia had not only a repellent CBB-effect as shown with the capture data but also a mulching effect, partly off-set by the competing vigour of the early Canavalia stand. Probably, these positive interactions improve the nutritional conditions through nutrient cycling. Growth and yield parameters were significant influenced by soil cover with Canavalia. The existence of management and phenology effects supports the need of undertaking carefully Canavalia cuts at full blossom. Mulching the Canavalia biomass under the coffee plants increases continuously the coffee yields. 


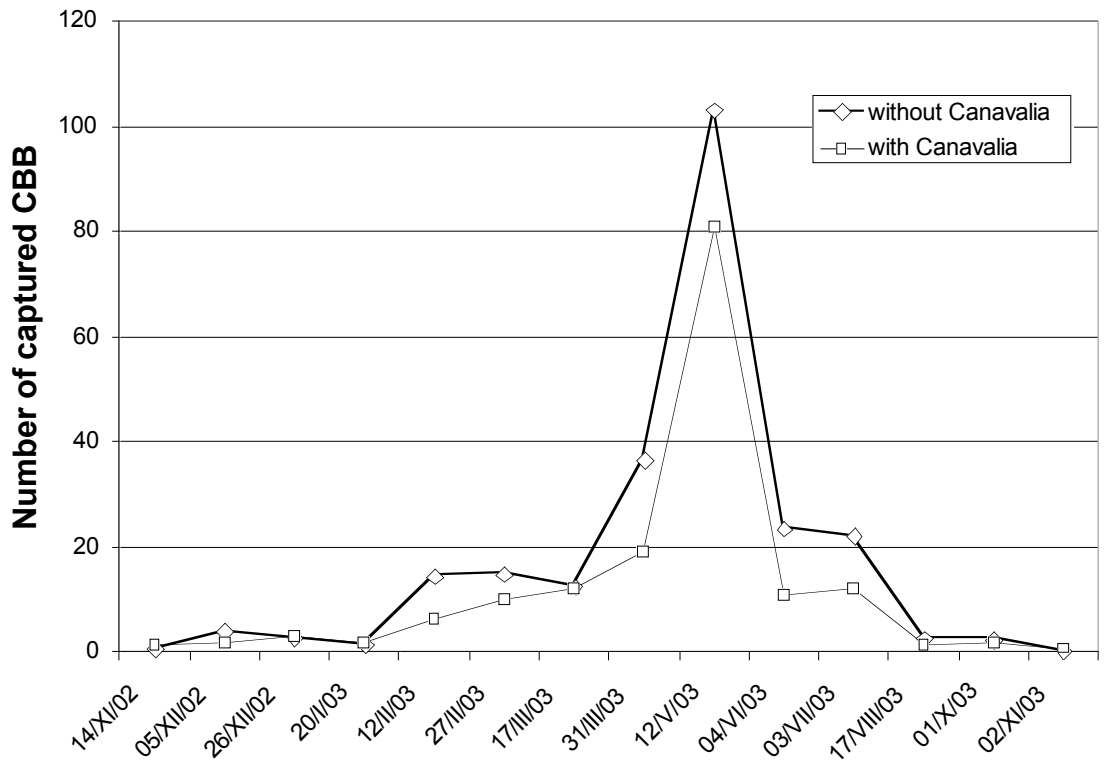

Fig. (3). Effects of soil cover on the dynamics of coffee berry borer capture (CBB).

Table 2. Abundance and Diversity of Different Insect Families Captured in the Coffee Plantation (Total Individuals from 32 Traps in 48 Hours)

\begin{tabular}{|c|c|c|c|c|c|c|c|c|c|c|c|}
\hline Date & Lepidoptera & Hemiptera & Coleoptera & Hymenoptera & Collembola & Araneae & Homoptera & Diptera & Orthoptera & Thysanoptera & Acari \\
\hline \multicolumn{12}{|c|}{ Trap Height $50 \mathrm{~cm}$} \\
\hline 14.11 .2002 & 7 & 25 & 33 & 835 & 9 & 9 & 104 & 72 & 21 & 18 & 1 \\
\hline 05.12 .2002 & 10 & 214 & 30 & 1136 & 15 & 2 & 191 & 89 & 67 & 4 & 2 \\
\hline 26.12 .2002 & 13 & 61 & 27 & 1781 & 34 & 0 & 143 & 50 & 62 & 13 & 8 \\
\hline 20.01 .2003 & 10 & 24 & 23 & 2505 & 13 & 8 & 121 & 54 & 41 & 26 & 2 \\
\hline 12.02.2003 & 2 & 18 & 22 & 3417 & 1 & 3 & 82 & 45 & 22 & 11 & 0 \\
\hline 27.02.2003 & 4 & 4 & 14 & 1118 & 6 & 0 & 75 & 24 & 47 & 2 & 0 \\
\hline 17.03.2003 & 6 & 22 & 30 & 2160 & 8 & 5 & 26 & 130 & 18 & 7 & 2 \\
\hline 31.03 .2003 & 2 & 7 & 18 & 1278 & 0 & 7 & 19 & 158 & 15 & 13 & 0 \\
\hline 12.05 .2003 & 1 & 5 & 16 & 2797 & 3 & 8 & 25 & 57 & 7 & 5 & 7 \\
\hline 04.06.2003 & 6 & 18 & 48 & 1010 & 68 & 0 & 113 & 79 & 26 & 6 & 0 \\
\hline 03.07.2003 & 5 & 25 & 49 & 1187 & 16 & 6 & 69 & 133 & 27 & 8 & 5 \\
\hline \begin{tabular}{|l|l|}
17.08 .2003 \\
\end{tabular} & 13 & 17 & 79 & 1074 & 25 & 10 & 90 & 66 & 76 & 1 & 25 \\
\hline 01.10.2003 & 36 & 4 & 36 & 1586 & 19 & 5 & 39 & 96 & 19 & 0 & 12 \\
\hline 02.11 .2003 & 2 & 7 & 31 & 373 & 8 & 6 & 52 & 138 & 26 & 5 & 5 \\
\hline \multicolumn{12}{|c|}{ Trap Height $150 \mathrm{~cm}$} \\
\hline 14.11 .2002 & 7 & 12 & 46 & 2897 & 2 & 4 & 62 & 82 & 7 & 5 & 4 \\
\hline 05.12 .2002 & 20 & 43 & 44 & 806 & 3 & 4 & 137 & 25 & 10 & 10 & 0 \\
\hline \begin{tabular}{|l|}
26.12 .2002 \\
\end{tabular} & 17 & 43 & 27 & 1145 & 6 & 2 & 54 & 28 & 7 & 5 & 0 \\
\hline 20.01 .2003 & 8 & 15 & 30 & 1123 & 11 & 2 & 20 & 105 & 3 & 10 & 1 \\
\hline 12.02 .2003 & 7 & 13 & 23 & 1276 & 1 & 7 & 29 & 36 & 22 & 4 & 1 \\
\hline \begin{tabular}{|l|}
27.02 .2003 \\
\end{tabular} & 7 & 8 & 31 & 808 & 0 & 3 & 23 & 23 & 9 & 1 & 0 \\
\hline 17.03.2003 & 19 & 9 & 35 & 1235 & 0 & 3 & 17 & 131 & 5 & 23 & 3 \\
\hline \begin{tabular}{|l|}
31.03 .2003 \\
\end{tabular} & 7 & 2 & 27 & 1256 & 0 & 6 & 25 & 101 & 2 & 12 & 0 \\
\hline 12.05 .2003 & 4 & 3 & 26 & 2203 & 0 & 4 & 14 & 191 & 1 & 17 & 1 \\
\hline \begin{tabular}{|c|}
04.06 .2003 \\
\end{tabular} & 10 & 13 & 55 & 855 & 1 & 4 & 63 & 44 & 4 & 1 & 0 \\
\hline 03.07 .2003 & 9 & 25 & 51 & 1202 & 7 & 14 & 63 & 96 & 20 & 5 & 5 \\
\hline 17.08 .2003 & 14 & 4 & 55 & 1171 & 0 & 11 & 50 & 107 & 15 & 2 & 3 \\
\hline 01.10 .2003 & 22 & 1 & 13 & 1609 & 4 & 12 & 24 & 119 & 19 & 2 & 0 \\
\hline 02.11.2003 & 11 & 3 & 23 & 1108 & 0 & 4 & 50 & 198 & 5 & 1 & 1 \\
\hline$\sum 50 \mathrm{~cm}$ & 117 & 451 & 456 & 22257 & 225 & 69 & 1149 & 1191 & 474 & 119 & 69 \\
\hline$\sum 150 \mathrm{~cm}$ & 162 & 194 & 486 & 18694 & 35 & 80 & 631 & 1286 & 129 & 98 & 19 \\
\hline
\end{tabular}




\section{Comprehensive Relations Between Soils Cover and Weed - Insect Associations}

Different studies reported that weeds serving as alternative hosts for pest arthropods and allelochemicals from weeds on the other hand, can introduce negative impacts against insect pests in agro-ecosystems [15-17]. Specifically, we wanted to determine how and when coffee berry borer moves into the coffee plantation, as well as the effect of soil cover plants and the height distribution of CBB invading two different strata. A better understanding of CBB dispersal and its possible interaction with the underlying herbaceous cover could prove useful for the use of either repellent crops, trap crops or ECO-IAPAR - traps. The population dynamics of CBB followed the known rhythm for the Soconusco coffee areas. Treatments with $C$. ensiformis presented smaller incidences of CBB during the whole year. That the $150 \mathrm{~cm}$ high traps captured more CBB than those at $50 \mathrm{~cm}$ height is an important result to determine strategies for the control of CBB with traps. It is recommendable to start trap activities at the end of March and finish the capture season at the end of May. The opposite values recorded in the two April treatments indicate that the effect of mulching under the coffee tree repelled the coffee borer towards higher position more than when leaving the Canavalia mulch between the rows. The coffee borer appears to prefer a humid and shaded habitat during the drier winter period.

The high importance of maintaining a stable selfregulating coffee ecosystem is well demonstrated by the rich number of individuals of different insect families which were captured together with the CBB. Also in this second part, the interactions between trap height and capture volumes of different insects are shown clearly.

\section{REFERENCES}

[1] Agreda MF, Pohlan J, Borgman J. Einfluss ökologischer Bewirtschaftung von Mais und Kaffee auf die Unkrautzönose und Bodenparameter von traditionellen Kaffeestandorten im Soconusco, Chiapas, Mexiko. Z PflKrankh PflSchutz Sonderh 2004; XIX: 627-34.

[2] Pohlan J. Complementary effects of weeds in coffee plantations in Chiapas, Mexico. Z PflKrankh PflSchutz Sonderh 2002; XVIII: 175-82.

[3] Friessleben U, Pohlan J, Franke G. The response of Coffea arabica L. to weed competition. Café Cacao Thé 1991; XXXV: 15-20.
Nestel D, Dickschen F, Altieri MA. Seasonal and spatial population loads of a tropical insect: the case of the coffee leaf-miner in Mexico. Ecol Entomol 1994; 19: 159-67.

[5] Aguilar V. Selective weed and ground cover management in a coffee plantation with shade trees in Nicaragua. Acta Univ Agric Sueciae 2001; 269.

[6] Staver C. Managing ground cover heterogeneity in coffee (Coffea arabica L.) under managed shade. In: Buck El, Lassoie PJ, Fernandes CHE, Eds. Agroforestry iin Sustainable Agricultural Systems. CRC Boca Ration, FL 1998; 67-96.

[7] López A, Pohlan J, Salazar D. Efectos agrobiológicos de coberturas verdes en el cultivo de la pitahaya (Hylocereus undatus Britton \& Rose) en Nicaragua. J Agric Rural Dev Trop Subtrop 2005; 105: 175-88.

[8] Leyva A, Pohlan J. Agroecología en el trópico - Ejemplos de Cuba, Aachen, Verlag Shaker 2005.

[9] Sun JH, Li ZC, Jewett DK, Britton KO, Ye WH, Ge XJ. Genetic diversity of Pueraria lobata (kudzu) and closely related taxa as revealed by inter-simple sequence repeat analysis. Weed Res 2005; 45: 255-60.

[10] Noris RF, Kogan M. Ecology of interactions between weeds and arthropods. Annu Rev Entomol 2005; 50: 479-503.

[11] Baker PS. La broca del café en Colombia. Informe final del proyecto MIP para el café, Cenicafe-CABI Bioscience, Chinchina, Colombia 1999

[12] Barrera JF, Villacorta A, Herrera J. Fluctuación estacional de las capturas de la broca del café (Hypothenemus hampei) con trampas de etanol - metanol e implicaciones sobre el número de trampas. Entomol Mex 2004; 3: 540-4

[13] Pohlan J. Manejo de la cenosis en cafetales y sus impactos sobre insectos, con especial énfasis en la broca del café. In: Barrera JF, Ed. Sociedad Mexicana de Entomología y El Colegio de la Frontera Sur Tapachula Chiapas, México 2005; pp. 22-30.

[14] Barrera JF. Manejo holístico de plagas: Hacia un nuevo paradigma de la protección fitosanitaria. In: Pohlan J, Soto L, Barrere JF, Eds. El cafetal del futuro: Realidades y Visiones, Shaker Verlag Aachen, Germany 2006; 63-82.

[15] Coombs MT. Seasonal phenology, parasitism, and evaluation of mowing as a control measure for Nezara viridula (Hemiptera: Pentatomidae) in Australian pecans. Environ Entomol 2000; 29: 102733.

[16] Gu H, Walter GH. Is the common sowthistle (Sonchus oleraceus) a primary host plant of the cotton bollworm, Helicoverpa armigera (Lep., Noctuidae)? Oviposition and larval performance. J Appl Entomol 1999; 123: 99-105.

[17] Adenir T, Klein A-M, Tscharntke T. Environmentally mediated coffee pest densities in relation to agroforestry management, using hierarchical partitioning analyses. Agric Ecosyst Environ 2008; 25: $120-6$. 